\title{
Ion Exchange Chromatography and Mass Bias Correction for Accurate and Precise Zn Isotope Ratio Measurements in Environmental Reference Materials by MC-ICP-MS
}

\author{
Daniel F. Araújo, ${ }^{*, a, b}$ Geraldo R. Boaventura, ${ }^{a}$ Jerôme Viers, ${ }^{b}$ Daniel S. Mulholland, ${ }^{c}$ \\ Dominik Weiss, ${ }^{d}$ Débora Araújo, ${ }^{e}$ Bárbara Lima, ${ }^{a}$ Izabel Ruiz, ${ }^{f}$ Wilson Machado, ${ }^{g}$ \\ Marly Babinskif and Elton Dantas ${ }^{a}$ \\ ${ }^{a}$ Instituto de Geociências, Universidade de Brasília, Campus Darcy Ribeiro, L2, Asa Norte, \\ 70910-900 Brasília-DF, Brazil \\ ${ }^{b}$ Géosciences Environnement Toulouse, GET-UMR 5563, Université Paul Sabatier, \\ CNRS, IRD, 14 Edouard Belin, 31400 Toulouse, France \\ 'Departamento de Química Ambiental, Universidade Federal do Tocantins, Rua Badejós, Lote 7, \\ Chácaras 69/72, Zona Rural, 77402-970 Gurupi-TO, Brazil \\ ${ }^{d}$ Earth Science and Engineering, Imperial College London, London SW7 2AZ, United Kingdom \\ ${ }^{e}$ Rio Tinto Exploration, 1 Research Ave, Bundoora VIC 3083, Australia

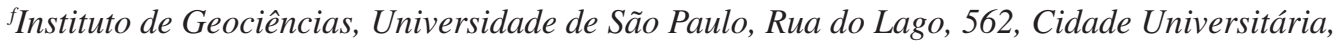 \\ 05508-080 São Paulo-SP, Brazil \\ ${ }^{8}$ Departamento de Geoquímica, Universidade Federal Fluminense, Campus do Valonguinho, \\ 24220-900 Niterói-RJ, Brazil
}

\begin{abstract}
Precise and accurate $\delta^{66 / 64} \mathrm{Zn}$ data for environmental reference materials (RMs) including rocks, sediments, soils and plants are presented in order to improve the metrological traceability and analytical control of $\mathrm{Zn}$ isotope ratio determinations in future environmental studies. Previously developed ion exchange chromatography protocols were adjusted to enable faster sample throughput and instrumental mass bias processes were investigated. The improved chromatographic protocol yielded precise and quantitative recoveries $(99 \pm 7 \%, \sigma, \mathrm{n}=16)$, while the mass bias correction using $\mathrm{Cu}$ as external dopant provided precisions better than $0.02 \%, 2 \sigma, \mathrm{n}=7$. Investigations into spectral and non-spectral interferences identified significant formation of $\mathrm{Cr}$ and $\mathrm{Ti}$ oxides and hydroxide ionic species. Analysis of six RMs (BHVO-2 basalt (USGS), BCR-2 basalt (USGS), AGV-2 andesite (USGS), 2709 San Joaquin soil (NIST), 1646a estuarine sediment (NIST) and 1573a tomato leaves (NIST)) showed good reproducibility $(<0.01 \%, 2 \sigma, 5 \leq n \geq 1)$.
\end{abstract}

Keywords: analytical geochemistry, $\mathrm{Zn}$ isotopes, isotope geochemistry, mass spectrometry, metal isotopes

\section{Introduction}

The advent of multi-collector inductively coupled plasma mass spectrometry (MC-ICP-MS) promoted the development of new research areas in the isotope geosciences, in particular the stable isotope biogeochemistry of transition metals such as $\mathrm{Cu}, \mathrm{Zn}, \mathrm{Fe}$ and others. ${ }^{1-3}$ Recent studies have shown the great potential of stable metal

*e-mail: danielunb.ferreira@gmail.com isotopes to identify contaminant sources,,${ }^{4,5}$ to constrain biogeochemical processes during nutrient cycling, ${ }^{6}$ weathering ${ }^{7,8}$ and to reconstruct metal transfer processes in complex systems such as the human body. ${ }^{9,10}$ Special attention has been given to $\mathrm{Zn}$ due to its key function as micronutrient in the biosphere and as pollutant in industrial, mining and urban environments. ${ }^{1-3,11}$

The natural variations in the $\mathrm{Zn}$ isotopic composition are small $(<1 \%$ ) , requiring reliable analytical procedures including chromatographic separation of $\mathrm{Zn}$ from the 
matrix $^{12-14}$ and accurate correction of the instrumental mass bias. ${ }^{14-16}$ To date, a number of ion exchange chromatographic protocols for specific sample types such as rocks, sediments, marine and fresh water, aerosols, plants and food has been published. ${ }^{17-26}$ Moreover, our understanding about instrumental controls of mass bias including effect of acid strength, dopant/analyte ratios, wet and dry plasma and matrix has improved..$^{27-32}$ However, the rapid advance of the stable metal isotope field has not been accompanied by the supply of reference materials (RMs), hindering the inter-laboratory studies and quality assurances. ${ }^{16}$ For $\mathrm{Zn}$ isotopic compositions, only two certified isotopic reference materials (iCRMs) are available commercially, supplied by the Institute for Reference Materials and Measurements (IRMM-651 and IRMM-3702). ${ }^{16,33}$ These two iCRMs are synthetic solutions whose matrices do not match with environmental and geological samples, hence they are not suitable for sample preparation and effect matrix control. ${ }^{16}$

To address this problem, many laboratories have analyzed certified reference materials for elemental concentrations. ${ }^{34}$ To date, the most available $\mathrm{Zn}$ isotopic data have been provided for silicate rocks such as the RMs BHVO-2 basalt, BCR-2 basalt and AGV-2 andesite. ${ }^{27}$ Data for RMs with environmental matrices such as soils, plants and sediments are rarely published, such that only one environmental RM (BCR-281 rye grass) ${ }^{20}$ was reported in a data compilation from different laboratories (see Table 1 from reference 11).

Thus, the improvement of metrological traceability, data quality control and methodological validation for the production of reliable and comparable data on metal isotopes analysis is of the utmost urgency. ${ }^{12,34}$

To address this gap, a method was set up for accurate and precise $\mathrm{Zn}$ isotopic measurements in environmental reference materials in two Brazilian laboratories (Laboratório de Geocrologia at University of Brasília (UnB) and Centro de Pesquisas Geocronológicas (CPGeo) at University of São Paulo (USP)). To this end, $(i)$ a fast and simple chromatographic separation for $\mathrm{Zn}$ was introduced and calibrated; ( ii) mass bias effects related to the analytedopant ratios $(\mathrm{Zn} / \mathrm{Cu})$ were assessed critically; (iii) effects of spectral and non-spectral interferences on $\mathrm{Zn}$ isotopic compositions were quantified; and (iv) new isotopic values for RMs of soils, sediments and plant matrices (2709 San Joaquin soil, 1646a estuarine sediment and 1573a tomato leaves) extending the data base for $\delta^{66 / 64} \mathrm{Zn}$ in materials relevant for environmental studies were determined. The database for previously analyzed RMs like the BHVO-2 basalt, BCR-2 basalt and AGV-2 andesite was further expanded.

\section{Experimental}

Reagents, standards and reference materials

The work was carried out under clean laboratory conditions in class 100 fume hoods, utilizing only Savillex ${ }^{\circledR}$ PFA labware. Ultrapure acids (Merck ${ }^{\circledR}$ ) distilled by sub-boiling in Teflon ${ }^{\circledR}$ stills, Merck Suprapur $\mathrm{H}_{2} \mathrm{O}_{2}$ $(30 \%)$ and de-ionized water (Milli-Q, $18.2 \mathrm{M} \Omega \mathrm{cm}$ ) were used. Multielement standard solutions (Merck $\left.{ }^{\circledR}\right)$ were used to produce calibration curves to measure $\mathrm{Cu}, \mathrm{Zn}$, $\mathrm{Na}, \mathrm{Fe}, \mathrm{Al}, \mathrm{Ca}, \mathrm{Mg}, \mathrm{Ti}, \mathrm{Cr}$ and $\mathrm{K}$ by inductively coupled plasma optical emission spectrometer (ICP OES) and quadrupole inductively coupled plasma mass spectrometry (Q ICP-MS).

The reference materials BHVO-2 basalt (US Geochemical Reference Materials and Certificates (USGS)), BCR-2 basalt (USGS) and the AGV-2 andesite (USGS) were used to assess the quantitative recovery of acid dissolution and ion exchange chromatography and the accuracy of the $\mathrm{Zn}$ isotope ratio determinations. The RM 2709 San Joaquin soil (National Institute of Standards and Technology (NIST)), 1646a estuarine sediment (NIST) and 1573a tomato leaves (NIST) were analyzed to extent the isotope data set for environmental reference materials. The RMs BHVO-2, BCR-2 and AGV-2 were processed and analyzed for comparison with literature data.

\section{Isotopic reference materials and data presentation}

Stable isotopic variations are reported as relative values compared to reference material and generally expressed in terms of $\delta$-values. ${ }^{1} \mathrm{Zinc}$ has five stable isotopes, ${ }^{64} \mathrm{Zn}$, ${ }^{6} \mathrm{Zn},{ }^{67} \mathrm{Zn},{ }^{68} \mathrm{Zn}$ and ${ }^{70} \mathrm{Zn}$, with average natural abundances of $48.63,27.90,4.10,18.75$ and $0.62 \%$, respectively. ${ }^{12}$ The isotope ratio $R\left({ }^{66} \mathrm{Zn} /{ }^{64} \mathrm{Zn}\right)$ is commonly used because of the highest abundance of the isotopes ${ }^{66} \mathrm{Zn}$ and ${ }^{64} \mathrm{Zn}$. In this work, the $\delta$-values of $\mathrm{Zn}$ isotopic composition are expressed in per mil relative to the $\mathrm{Zn}$ standard Merck (No. 9953), henceforward labeled Zn UnB:

$\delta^{66 / 64} \mathrm{Zn}_{\mathrm{UnB}}(\%)=\left(\frac{\mathrm{R}\left({ }^{66} \mathrm{Zn} /{ }^{64} \mathrm{Zn}\right)_{\text {sample }}}{\mathrm{R}\left({ }^{66} \mathrm{Zn} /{ }^{64} \mathrm{Zn}\right)_{\mathrm{UnB}}}-1\right)$

Since common RMs are established as zero baseline for isotopic analyses, the results of different laboratories can be compared. ${ }^{11,12}$ To date, the $\delta^{66 / 64} \mathrm{Zn}$ values have been reported in relation to the RM Johnson Matthey ${ }^{\circledR}$ zinc (JMC 3-0749), labeled as $\delta^{66 / 64} \mathrm{Zn}_{\mathrm{JMC}}{ }^{11,12}$ Since this standard is no longer available, the $\mathrm{Zn}$ isotopic certified reference material from IRMM (IRMM-3702 (Zn)) has 
been adopted $\left(\delta^{66 / 64} \mathrm{Zn}_{\text {IRMM }}\right) \cdot{ }^{27}$ Our Zn UnB Merck solution was calibrated against Zn JMC 3-0749 and IRMM-3702 to enable comparisons with values from literature.

\section{Dissolution of reference materials}

Soil, sediment and rock reference materials (RMs) were weighed in Savillex Teflon ${ }^{\circledR}$ beakers, with sample masses ranging from 20 to $150 \mathrm{mg}$, and digested using a multiplestep acid attack on a hot plate: (i) $1 \mathrm{~mL}$ of $14 \mathrm{~mol} \mathrm{~L}^{-1}$ $\mathrm{HNO}_{3}+4 \mathrm{~mL}$ of $21 \mathrm{~mol} \mathrm{~L}^{-1} \mathrm{HF}$ for $48 \mathrm{~h}$; drying at $100^{\circ} \mathrm{C}$; (ii) $3 \mathrm{~mL}$ of $6 \mathrm{~mol} \mathrm{~L}^{-1} \mathrm{HCl}+1 \mathrm{~mL}$ of $14 \mathrm{~mol} \mathrm{~L}^{-1} \mathrm{HNO}_{3}$ for $24 \mathrm{~h}$; drying at $100^{\circ} \mathrm{C}$; (iii) $1 \mathrm{~mL}$ of $6 \mathrm{~mol} \mathrm{~L}^{-1} \mathrm{HCl}+0.5 \mathrm{~mL}$ of $14 \mathrm{~mol} \mathrm{~L}^{-1} \mathrm{HNO}_{3}$ for $24 \mathrm{~h}$; drying at $100{ }^{\circ} \mathrm{C}$; (iv) $1 \mathrm{~mL}$ of $6 \mathrm{~mol} \mathrm{~L}^{-1} \mathrm{HCl}$. Subsequently, the samples were dried again and re-dissolved in $1 \mathrm{~mL}$ of $2 \mathrm{~mol} \mathrm{~L}^{-1} \mathrm{HCl}$ prior to $\mathrm{Zn}$ chromatographic purification (protocol details in the following sections). Blanks and RMs (BCR-2 or BHVO-2) were included in every sample batch as analytical controls in the elemental analysis. For the plant reference material (1573a tomato leaves), the digestion was performed using microwave digestion (Speedwave 4, Berghof) with an acid mixture of $3 \mathrm{~mL}$ of $21 \mathrm{~mol} \mathrm{~L}^{-1} \mathrm{HF}+5 \mathrm{~mL}$ of $14 \mathrm{~mol} \mathrm{~L}^{-1}$ $\mathrm{HNO}_{3}+4 \mathrm{~mL}$ of $6 \mathrm{~mol} \mathrm{~L}^{-1} \mathrm{HCl}$. After digestion, the solution was transferred to Savillex Teflon ${ }^{\circledR}$ beakers dried on a hot plate at $100{ }^{\circ} \mathrm{C}$, dissolved in $1 \mathrm{~mL}$ of $2 \mathrm{~mol} \mathrm{~L}^{-1} \mathrm{HCl}$, dried again and re-dissolved in $1 \mathrm{~mL}$ of $2 \mathrm{~mol} \mathrm{~L}^{-1} \mathrm{HCl}$.

\section{Determination of elemental concentration}

Zinc concentrations in the acid dissolutions were determined using ICP OES (Spectroflame FVM03, Spectro Analytical Instrumental GmbH). Zinc in the purified fractions after chromatographic separation and in the procedural blanks were analyzed using Q ICP-MS (X Series 2, Thermo Scientific). The isotopes ${ }^{66} \mathrm{Zn},{ }^{68} \mathrm{Zn}$, ${ }^{49} \mathrm{Ti},{ }^{47} \mathrm{Ti},{ }^{52} \mathrm{Cr},{ }^{53} \mathrm{Cr},{ }^{56} \mathrm{Fe}$ and ${ }^{57} \mathrm{Fe}$ were analyzed in CCT mode (collision cell technology), and ${ }^{43} \mathrm{Ca},{ }^{43} \mathrm{Ca},{ }^{27} \mathrm{Al},{ }^{24} \mathrm{Mg}$, ${ }^{25} \mathrm{Mg}$ and ${ }^{23} \mathrm{Na}$ were analyzed in the standard mode. The accuracy of the concentration determinations in ICP OES and Q ICP-MS was verified with the certified values of the RMs BHVO-2 and BCR-2. The determined elemental concentrations were always within $10 \%$ of the certified values.

Zinc chromatographic separation: column specifications and development of the elution protocol

The zinc separation procedure was developed using Poly-prep Bio-Rad chromatography columns with $2 \mathrm{~mL}$ of bed volume $(0.8 \times 4 \mathrm{~cm})$ and $9 \mathrm{~cm}$ height, loaded with
AG MP1 Bio-Rad macro porous resins (100-200 mesh) and was based on the protocol originally published for the separation of $\mathrm{Zn}, \mathrm{Cu}$ and $\mathrm{Fe} .{ }^{12}$

Since $\mathrm{Zn}$ was the only element of interest, the protocol was modified to reduce time, reagents and sample mass (Table 1). In our protocol, the sample is directly loaded in the column with a molarity of $2 \mathrm{~mol} \mathrm{~L}^{-1}$, where $\mathrm{Zn}$ has a high sorptive capacity for the resin AG MP- $1,{ }^{35}$ thus avoiding undesirable losses of $\mathrm{Zn}$ during the matrix elution process.

Table 1. Original protocol of Maréchal et al. ${ }^{12}$ and the modified protocol used in this study

\begin{tabular}{lcc}
\hline \multicolumn{3}{c}{ Maréchal et al. ${ }^{12}$ protocol } \\
\hline Step & Volume $/ \mathrm{mL}$ & Eluent \\
\hline Column conditioning & 6 & $7 \mathrm{~mol} \mathrm{~L}^{-1} \mathrm{HCl}+0.001 \% \mathrm{H}_{2} \mathrm{O}_{2}$ \\
Sample loading & 1 & $7 \mathrm{~mol} \mathrm{~L}^{-1}+0.001 \% \mathrm{H}_{2} \mathrm{O}_{2}$ \\
Matrix elution & 10 & $7 \mathrm{~mol} \mathrm{~L}^{-1}+0.001 \% \mathrm{H}_{2} \mathrm{O}_{2}$ \\
Cu elution & 20 & $7 \mathrm{~mol} \mathrm{~L}^{-1}+0.001 \% \mathrm{H}_{2} \mathrm{O}_{2}$ \\
Fe elution & 10 & $2 \mathrm{~mol} \mathrm{~L}^{-1} \mathrm{HCl}$ \\
Rinse & 2 & $0.5 \mathrm{~mol} \mathrm{~L}^{-1} \mathrm{HNO}_{3}$ \\
Zn elution & 8 & $0.5 \mathrm{~mol} \mathrm{~L}^{-1} \mathrm{HNO}_{3}$
\end{tabular}

Quartz column; high column: $4.3 \mathrm{~cm}$; resin volume: $1.6 \mathrm{~mL}$

\begin{tabular}{lcc}
\hline \multicolumn{3}{c}{ Modified protocol - this study } \\
\hline Step & Volume / mL & Eluent \\
\hline Column conditioning & 10 & $2 \mathrm{~mol} \mathrm{~L}^{-1} \mathrm{HCl}$ \\
Sample loading & 1 & $2 \mathrm{~mol} \mathrm{~L}^{-1} \mathrm{HCl}$ \\
Matrix elution & 20 & $2 \mathrm{~mol} \mathrm{~L}^{-1} \mathrm{HCl}$ \\
Zn elution & 12 & $0.5 \mathrm{~mol} \mathrm{~L}^{-1} \mathrm{HNO}_{3}$ \\
Biorad $^{\circledR}$ column; height column: $5.0 \mathrm{~cm}$; resin volume: $2.0 \mathrm{~mL}$
\end{tabular}

The mass of sample loaded on the column was calculated to avoid saturation of exchange sites since amounts of $\mathrm{Fe}>20 \%$ of theoretical resin saturation can lead to the early elution of light $\mathrm{Zn}$ isotopes and induce its fractionation. ${ }^{13}$ Thus, the content of $\mathrm{Fe}$ in each sample was calculated so as not to exceed this value. Considering that the theoretical capacity of AG MP1 Bio-Rad resin is $1 \mathrm{meq} \mathrm{mL}^{-1}, 2 \mathrm{~mL}$ of resin support $4 \times 10^{-4} \mathrm{~mol}$ or $22.4 \mathrm{mg}$ of Fe. ${ }^{13}$ The resin was cleaned by passing three times $5 \mathrm{~mL}$ of $0.5 \mathrm{~mol} \mathrm{~L}^{-1} \mathrm{HNO}_{3}$ and $5 \mathrm{~mL}$ of de-ionized water before and after each chromatographic procedure.

\section{Assessment of the ion exchange chromatography procedure}

The RMs 1646a estuarine sediment (NIST), 1573a tomato leaves (NIST), BHVO-2 basalt (USGS), BCR-2 basalt (USGS) and AGV-2 andesite (USGS) were used to assess the chromatographic separation with respect to recovery, reproducibility and matrix separation efficiency. 
The recovery of $\mathrm{Zn}$ is a critical methodological step for its accurate isotopic determination since the ionic exchange process along the chromatographic column induces isotope fractionation throughout the $\mathrm{Zn}$ elution. ${ }^{36}$ The recovery was calculated from the difference between the amount of mass $\mathrm{Zn}$ recovered from purified solution at the end of chromatographic separation and the amount of $\mathrm{Zn}$ initially loaded on the column. The amount of $\mathrm{Zn}$ loaded on the column (1 to $3.5 \mu \mathrm{g}$ ) was calculated using the certified values of the elemental standards and RMs. The reproducibility was estimated as the relative standard deviation (RSD) from the $\mathrm{Zn}$ mass recovery of different replicates. In addition, possible chromatographic isotopic fractionation on the column was assessed measuring the $\mathrm{Zn}$ isotopic composition of the RM Zn UnB before and after the ion exchange procedure using the proposed protocol.

Matrix separation efficiency was assessed analyzing the residual matrix elements ( $\mathrm{Ti}, \mathrm{Cr}, \mathrm{Al}, \mathrm{Fe}, \mathrm{Mg}$ and $\mathrm{Ca}$ ) in the $\mathrm{Zn}$ fractions of RMs after passing through the column. Procedural blanks of the entire analytical protocol including digestion and chromatographic separation were performed during the processing of the sample batches.

\section{Zinc isotope ratio measurements}

Zinc isotopic compositions of sediment sample and reference materials were measured using a ThermoFinnigan Neptune MC-ICP-MS in the Laboratório de Geocronologia (UnB) and CPGeo (USP). Both instruments were configured in similar ways using the same inlet system, cones and acid concentrations. The typical operating conditions of the Neptune from both laboratories are shown in Table 2.

The inlet system consisted of a stable introduction system (SIS) composed by a tandem quartz glass spray chamber (cyclone plus standard Scott double pass) coupled with a low flow PFA nebulizer $\left(50 \mu \mathrm{L} \mathrm{min}{ }^{-1}\right)$. The masses $62(\mathrm{Ni}), 63(\mathrm{Cu}), 64(\mathrm{Zn} / \mathrm{Ni}), 65(\mathrm{Cu}), 66(\mathrm{Zn}), 67(\mathrm{Zn})$ and 68 (Zn) were simultaneously detected using Faraday cups.

The analytical sequences ran automatically using a Cetac ASX-100 autosampler and low mass resolution collector slits, matching $\mathrm{Cu}$ and $\mathrm{Zn}$ concentrations at $300 \mu \mathrm{g} \mathrm{L}^{-1}$. Using the standard-sample bracketing technique, each sample was bracketed by a mixed isotopic reference solution ( $\mathrm{Zn} \mathrm{UnB} \mathrm{+} \mathrm{Cu} \mathrm{NIST} \mathrm{SRM} \mathrm{976)}$ with rinses between sample and standard analyses with $0.05 \mathrm{~mol} \mathrm{~L}^{-1} \mathrm{HNO}_{3}$ from two different vials for 1 min each. Blank measurements consisted of 1 block of 10 cycles $(8 \mathrm{~s})$, while samples and isotopic reference solution were measured in 2 blocks of 20 cycles of $8 \mathrm{~s}$ each. For a single measurement (40 cycles), internal precision ranged from
Table 2. Typical Neptune operating conditions of the USP and UnB laboratories

\begin{tabular}{lcc}
\hline & CPGeo - USP & Geocronologia - UnB \\
\hline Extraction / V & -2000.0 & -1816.3 \\
Focus / V & -720.1 & -651.7 \\
Source quad1 / V & 248.0 & 248.7 \\
Rot-quad 1 / & -6.6 & -2.7 \\
Foc-quad 1 / & -19.5 & -19.4 \\
Rot-quad / / & -0.1 & 28.8 \\
Source offset / V & 20.0 & 0.0 \\
Matsuda plate / V & -1.0 & 0.0 \\
Cool gas / (L min $\left.{ }^{-1}\right)$ & 16.5 & 15.3 \\
Aux gas / (L min $\left.{ }^{-1}\right)$ & 0.8 & 0.7 \\
Sample gas / $\left(\mathrm{L} \mathrm{min}^{-1}\right)$ & 1.1 & 1.0 \\
Operation power / W & 1303 & 1263 \\
X-pos / mm & 0.6 & 1.6 \\
Y-pos / mm & -2.6 & -4.8 \\
Z-pos / mm & -3.2 & -7.0 \\
Amplifier temperature / ${ }^{\circ} \mathrm{C}$ & 46.79 & 45.86 \\
Fore vacuum / mbar & $1.61 \times 10^{-3}$ & $1.43 \times 10^{-3}$ \\
High vacuum / mbar & $1.38 \times 10^{-7}$ & $1.12 \times 10^{-7}$ \\
Ion getter press / mbar & $1.8 \times 10^{-8}$ & $1.31 \times 10^{-8}$ \\
\hline Nicone & &
\end{tabular}

Ni cone

Low resolution

CPGeo: Laboratório de Geocronologia at University of Brasília (UnB); CPGeo: Centro de Pesquisas Geocronológicas at University of São Paulo (USP).

3 to $8 \mathrm{ppm}(2 \sigma)$ for both $\mathrm{Cu}$ and $\mathrm{Zn}$. An on-peak baseline correction was applied to correct instrumental and acid blank interference.

The $\mathrm{Zn}$ isotopic determinations of the RM samples were carried out on replicates prepared in separate batches (thus, separate digestion and chromatography for each batch). AGV-2 RM was prepared using a single aliquot.

Instrumental mass bias corrections

Mass bias (or instrumental fractionation) is a process in which isotopes of the same chemical element are transmitted with different efficiencies by the mass spectrometer resulting in non-uniform sensitivity across the mass range and inaccurate isotope ratio measurements. ${ }^{14,15,29,31,37}$

The simplest technique used to correct mass bias is sample standard bracketing (SSB), consisting of analyzing an unknown sample bracketed by standards that are used to interpolate and correct the mass bias drift during data collection. ${ }^{15,31}$ The SSB approach assumes that temporal drift in mass bias between bracketing standards is predictable and approximates to a simple mathematical expression (typically a linear interpolation), requiring a stable mass bias over the measurement session with no significant matrix-induced mass bias. . $^{15,29,31}$ 
Another technique widely applied is the external normalization which consists of doping samples and standard with an element with a known isotope composition and similar fractionation behavior to the element being analyzed (e.g., $\mathrm{Zr}$ doping to Mo isotope analysis, $\mathrm{Mg}$ doping for $\mathrm{Si}$ and $\mathrm{Cu}$ doping for $\mathrm{Zn}$ isotope analysis). ${ }^{15,31,38}$ The measured isotope ratio of the dopant can be compared to its known value to quantify instrumentinduced fractionation (or factor of fractionation $(f)$ ) and a correction can then be applied to the isotope ratio of the target element. ${ }^{15,31,38}$ Different mathematical laws are used to associate the true isotopic composition with the measured values and the respective $f$ values. For the instrumental fractionation (mass bias) of $\mathrm{Zn}$ and $\mathrm{Cu}$, the exponential law (equation 2) has been indicated as the most appropriate law to describe it: ${ }^{12}$

$\mathrm{R}_{\text {meas }}=\mathrm{R}_{\text {true }}\left(\frac{\operatorname{mass}{ }^{i} E}{\operatorname{mass}{ }^{j} E}\right)^{f}$

where ${ }^{i} E$ and ${ }^{j} E$ represent the masses of isotopes $i$ and $j$ of the analyte-element $E ; \mathrm{R}_{\text {meas }}$ and $\mathrm{R}_{\text {true }}$ represent the isotopic ratios experimentally measured and the true isotopic ratio of the analyte-element $E$, respectively.

Maréchal et al. ${ }^{12}$ demonstrated that $\mathrm{Cu}$ and $\mathrm{Zn}$ isotopes do not fractionate to the same extent but the empirical relationship of $f(\mathrm{Cu}) / f(\mathrm{Zn})$ can be determined plotting the natural logarithm of the raw $\mathrm{Cu}$ and $\mathrm{Zn}$ isotope ratios of standards measured during an analytical session and can be used to correct the measured ratios of the analyte element. The corrected $\mathrm{R}\left({ }^{66} \mathrm{Zn} /{ }^{64} \mathrm{Zn}\right)$ ratios for each sample and its bracketing standards are used to calculate the $\delta^{6 / / 64} \mathrm{Zn}$ values by $\delta$-equation (equation 1 ). In this work, external normalization was performed by doping samples and bracketing standards with Cu NIST SRM 976. The certified isotopic value of 0.4456 was used to correct the $\mathrm{Zn}$ isotopic ratios by the application of the exponential law. ${ }^{12}$

\section{Effect of variable analyte-dopant $(\mathrm{Zn} / \mathrm{Cu})$ ratios on MC-ICP-MS}

The extent of mass bias is a function of the analytedopant $(\mathrm{Zn} / \mathrm{Cu})$ ratio and plasma condition (wet versus dry). ${ }^{19,23}$ Wet plasma conditions show a stronger effect of the $\mathrm{Zn} / \mathrm{Cu}$ ratio compared to the dry plasma (using Aridus I, DSN-100 or Apex HF), likely because of stronger turbulence effects during ionization, vaporization, atomization and excitation. ${ }^{23}$ To this end, an experiment with sequential analysis of a mixed isotopic reference solution (Zn UnB + Cu NIST SRM 976) with variable concentration ratios ranging from 1 to 8 was conducted.
The $\delta$-values were calculated using the SSB and external normalization approaches to compare accuracy and precision for different concentration ratios $(\mathrm{Cu} / \mathrm{Zn})$ and mass bias correction methods. This experiment also allows the identification of the best $\mathrm{Cu} / \mathrm{Zn}$ ratio to be used in the established method and offers a good opportunity to verify similarities and differences between instruments of the same model under different laboratory conditions.

\section{Spectral and non-spectral interferences}

Matrix elements induce spectral (isobaric) and non-spectral (matrix effects) interferences, inducing suppression or enhancement of signals, changes on sensitivity and instrumental mass bias, and overlap between the analyte isotopes and other elemental isobars (e.g., ${ }^{64} \mathrm{Ni}$ at ${ }^{64} \mathrm{Zn}$ ), polyatomic ion species such as oxides $(\mathrm{MO})^{+}$and hydroxides $(\mathrm{MOH})^{+}$or double charged ions (e.g., ${ }^{48} \mathrm{Ca}^{2+}$ at ${ }^{24} \mathrm{Mg}$ ). ${ }^{19,29,30}$

Even in post-chromatographic separation procedures, some residual matrix elements can remain in the purified sample solution, affecting the accurate and precise determinations of $\mathrm{Zn}$ isotope ratios. As demonstrated in previous studies, ${ }^{19,30} \mathrm{Zn}$ solutions doped with different elements ( $\mathrm{Na}, \mathrm{Fe}, \mathrm{Mg}, \mathrm{Al}, \mathrm{Ti}, \mathrm{V}, \mathrm{Cr}, \mathrm{Ba}$ and $\mathrm{Ce}$ ) showed different magnitudes of interference on the $\mathrm{Zn}$ isotopic ratios, which $\mathrm{Cr}$ and Ti oxides and hydroxide ion species formed in the plasma were the main isobaric interferences for $\mathrm{Zn}$ isotopes. Other polyatomic species formed in the plasma (such as ${ }^{27} \mathrm{Al}^{40} \mathrm{Ar}^{+}$) can cause strong isobaric interference while remaining major elements as $\mathrm{Fe}$ can induce matrix effects on $\mathrm{Zn}$ isotope ratio measurements. ${ }^{19,30}$ These studies, however, were carried out on VG Axiom, MicroMass Isoprobe and $\mathrm{Nu}$ Plasma, ${ }^{19,30}$ instead of in a MC-ICP-MS Neptune instrument.

In this work, we assessed the potential interferences of $\mathrm{Fe}, \mathrm{Cr}, \mathrm{Al}, \mathrm{Ti}, \mathrm{Mg}, \mathrm{Na}$ and $\mathrm{Ca}$ in a Neptune MC-ICP-MS, doping the isotopic reference solution (Cu NIST SRM $976+$ Zn UnB) with these representative matrix elements in the proportion of $1: 1$ at concentrations of $300 \mu \mathrm{g} \mathrm{L}^{-1}$. The interference magnitude on $\mathrm{Zn}$ isotope ratios was estimated using the $\delta^{6 / 64} \mathrm{Zn}_{\mathrm{UnB}}$ values for the doped reference isotopic solution against the average of the undoped bracketed isotopic reference solution using SSB and external normalization for mass bias correction.

\section{Results and Discussion}

Assessing the ion exchange chromatographic procedure: recovery, reproducibility, matrix separation and blanks

The experiment of $\mathrm{Zn}$ recovery using replicates of RMs is shown in Table 3. The chromatographic procedure 
yielded, on average, recovery of $99.3 \pm 7.1 \%(\sigma, \mathrm{n}=16)$, which falls within the relative error of $\pm 10 \%$ for the certified concentration values of the CRMs analyzed by ICP OES and Q ICP-MS in our laboratories. Average reproducibility of replicates was ca. 5\%, expressed as percentage of relative standard deviation of the replicates, indicating that the procedure including digestion and chromatographic separation is robust, and confirming quantitative recovery during the separation process. The RMs processed on the column and analyzed by MC-ICP-MS in an intra-run showed $\delta^{66 / 64} \mathrm{Zn}$ values of $0.01 \pm 0.02 \%$ ( 3 replicates, $\sigma$, $\mathrm{n}=6$ measurements). This uncertainty is well within the reproducibility estimated from repeated measurements of the iCRM Zn IRMM-3702 relative to the RM Zn UnB during several analytical session-days $( \pm 0.03 \%$ o, $\mathrm{n}=30$, Table 4), confirming that the chromatographic column does not induce significant isotopic fractionation on the samples.

The Q ICP-MS scan of all the samples and most of the certified reference materials processed using the ion exchange procedure showed efficient separation of potential interfering elements and $\mathrm{Al} / \mathrm{Zn}, \mathrm{Mg} / \mathrm{Zn}, \mathrm{Ca} / \mathrm{Zn}, \mathrm{Na} / \mathrm{Zn}$, $\mathrm{Ti} / \mathrm{Zn}$ and $\mathrm{Cr} / \mathrm{Zn}$ ratio were all below 0.001 . The purified $\mathrm{Zn}$ fractions were free from the main potential interfering metals ( $\mathrm{Cr}$ and $\mathrm{Ti})$. The reference materials BHVO-2 (basalt) and estuarine sediment 1646a had Fe remaining after the chromatographic separation with $\mathrm{Fe} / \mathrm{Zn}$ values corresponding to 0.12 and 0.02 , respectively.

The blank contribution of our total procedure, including dissolution reagents and chromatography elution, was about $44 \pm 14 \mathrm{ng}(\sigma, \mathrm{n}=6)$, which corresponds to less than $0.1 \%$ of the total $\mathrm{Zn}$ found in samples. This low blank did not require any additional corrections.

Determining the optimum analyte-dopant ratio $(\mathrm{Zn} / \mathrm{Cu})$ of isotopic measurements

The effect of variable $\mathrm{Cu} / \mathrm{Zn}$ ratios on the mass bias was investigated using bi-variant plots of raw $\mathrm{Cu}$ and $\mathrm{Zn}$ isotope ratios (i.e., ratios uncorrected for the mass bias effect) of standards in the $1 n$-ln space (Figure 1). Straight lines indicating constant instrumental fractionation behavior of $\mathrm{Zn}$ and $\mathrm{Cu}$ confirming invariable $f(\mathrm{Zn}) / f(\mathrm{Cu})$ over the analytical sessions were found consistently. The slope ranges between 0.99 and 1.22 for the different $\mathrm{Cu} / \mathrm{Zn}$ ratios, however, demonstrate that the mass bias behavior of $\mathrm{Zn}$ and $\mathrm{Cu}$ depends on the analyte/dopant ratio. Our results reinforce the importance of verifying empirically the relationship between the factor of fractionation of $\mathrm{Zn}$ $(f(\mathrm{Zn}))$ and $\mathrm{Cu}(f(\mathrm{Cu}))$ for each analytical season if SBB is used, and also highlight the importance of matching dopant $(\mathrm{Cu})$ analyte $(\mathrm{Zn})$ concentrations of samples and standards. ${ }^{23}$

Table 5 shows the $\delta^{66 / 64} \mathrm{Zn}$ values and precision (expressed as $2 \sigma$ of the total number measurements) of the mixed reference isotopic solution ( $\mathrm{Zn} \mathrm{UnB}+\mathrm{Cu}$ NIST SRM 976) analyzed sequentially with different ratios of $\mathrm{Cu} / \mathrm{Zn}$. We found that variable $\mathrm{Cu} / \mathrm{Zn}$ ratios do not have significant effects on the accuracy of $\delta^{66} \mathrm{Zn}$ values (all $\delta^{66} \mathrm{Zn}$ values obtained were close to $0.00 \pm 0.01 \%, \sigma$, $\mathrm{n}=31$ ). However, the analytical precision (or external

Table 3. Zinc recovery yield and reproducibility data obtained for replicates of reference materials (RMs)

\begin{tabular}{|c|c|c|c|c|}
\hline Replicate $^{\mathrm{a}}$ & Zn mass loaded / $\mu \mathrm{g}$ & $\mathrm{Zn}$ mass recovered $/ \mu \mathrm{g}$ & Recovery / \% & Reproducibility $/ \%^{\mathrm{b}}$ \\
\hline $\mathrm{Zn} \mathrm{UnB}$ & 1.0 & 0.95 & 95.0 & 1.5 \\
\hline $\mathrm{Zn} \mathrm{UnB}{ }^{\mathrm{a}}$ & 1.0 & 0.93 & 93.0 & \\
\hline BHVO-2 Basalt - a & 1.0 & 1.08 & 108.0 & 4.9 \\
\hline BHVO-2 Basalt - a & 1.0 & 1.01 & 100.8 & \\
\hline BCR-2 Basalt - a & 2.5 & 2.50 & 99.8 & 2.8 \\
\hline BCR-2 Basalt - b & 2.5 & 2.40 & 96.0 & \\
\hline San Joaquin soil - a & 5.0 & 5.15 & 103.0 & 5.4 \\
\hline San Joaquin soil - b & 5.0 & 4.77 & 95.4 & \\
\hline 1646a Estuarine sediment - a & 3.5 & 3.65 & 104.2 & 7.0 \\
\hline 1646a Estuarine sediment - b & 3.5 & 3.07 & 87.8 & \\
\hline 1646a Estuarine sediment - c & 3.5 & 3.36 & 96.0 & \\
\hline 1646a Estuarine sediment - d & 3.5 & 3.36 & 96.0 & \\
\hline 1573a Tomato leaves - a & 5.0 & 5.28 & 105.6 & 11.4 \\
\hline 1573a Tomato leaves - b & 5.0 & 5.88 & 117.6 & \\
\hline 1573a Tomato leaves - c & 5.0 & 4.68 & 93.6 & \\
\hline AGV Andesite & 1.0 & 0.97 & 97.2 & \\
\hline Average & & & $99.3 \pm 7.1$ & 5.2 \\
\hline
\end{tabular}

${ }^{a}$ Replicates are indicated by different letters (a, b, c and d). For AGV-2 andesite, only one test-portion was analyzed; bthe reproducibility is expressed as the percentage of the relative standard deviation of $\mathrm{Zn}$ recovery masses for the different replicates. 
Table 4. Results of zinc isotope determinations of reference isotopic standards and reference materials (RMs)

\begin{tabular}{|c|c|c|c|c|}
\hline Isotopic standard / RM & Reference & $\delta^{66 / 64} \mathrm{Zn} \mathrm{JMC}$ & $\delta^{66 / 64} \mathrm{Zn} \mathrm{UnB}$ & $\mathrm{n}$ (replicates) $)^{\mathrm{b}}$ \\
\hline \multirow{2}{*}{ IRMM-3702 } & this study & $-0.27 \pm 0.07$ & $0.13 \pm 0.03$ & $30(1)$ \\
\hline & Moeller et al. ${ }^{27}$ & $-0.30 \pm 0.05^{\mathrm{a}}$ & & \\
\hline \multirow{5}{*}{ BHVO-2 Basalt } & this study & $0.25 \pm 0.09$ & $0.08 \pm 0.08$ & $10(5)$ \\
\hline & Herzog et al. ${ }^{39}$ & $0.29 \pm 0.09$ & & \\
\hline & Moynier et al..$^{40}$ & $0.21 \pm 0.09$ & & \\
\hline & Moeller et al. ${ }^{27}$ & $0.48 \pm 0.13$ & & 3 \\
\hline & Chen et $a{ }^{43}$ & $0.33 \pm 0.04$ & & \\
\hline \multirow{7}{*}{ BCR-2 Basalt } & this study & $0.25 \pm 0.08$ & $0.08 \pm 0.06$ & $10(5)$ \\
\hline & Archer and Vance ${ }^{32}$ & $0.20 \pm 0.09$ & & 12 \\
\hline & Chapman et al..$^{13}$ & $0.29 \pm 0.12$ & & 8 \\
\hline & Cloquet et al..$^{11}$ & $0.32 \pm 0.13$ & & 2 \\
\hline & Sonke et $a ._{.}^{5}$ & $0.25 \pm 0.04$ & & 4 \\
\hline & Herzog et al. ${ }^{39}$ & $0.33 \pm 0.09$ & & \\
\hline & Moeller et al. ${ }^{27}$ & $0.33 \pm 0.13$ & & 3 \\
\hline \multirow{3}{*}{ AGV-2 Andesite } & this study & $0.29 \pm 0.06$ & $0.12 \pm 0.03$ & $2(1)$ \\
\hline & Moynier et al. ${ }^{40}$ & $0.25 \pm 0.09$ & & \\
\hline & Chen et al. ${ }^{43}$ & $0.32 \pm 0.04$ & & \\
\hline 2709 San Joaquin soil & this study & $0.28 \pm 0.10$ & $0.11 \pm 0.09$ & $4(2)$ \\
\hline 1646a Estuarine sediment & this study & $0.32 \pm 0.06$ & $0.15 \pm 0.04$ & $4(2)$ \\
\hline 1573a Tomato leaves & this study & $0.79 \pm 0.09$ & $0.62 \pm 0.07$ & $4(2)$ \\
\hline
\end{tabular}

JMC: Johnson Matthey ${ }^{\oplus}$; UnB: University of Brasília; n: number of measurements. ${ }^{a}$ The value reported represents the average of the values published in the literature; ${ }^{11,14,19}$ bor the standards and reference materials analyzed in this study, the number of replicates is indicated in the parentheses. Each replicate was prepared separately with different digestions and chromatographic separation for the determination of the $\mathrm{Zn}$ isotopic compositions.

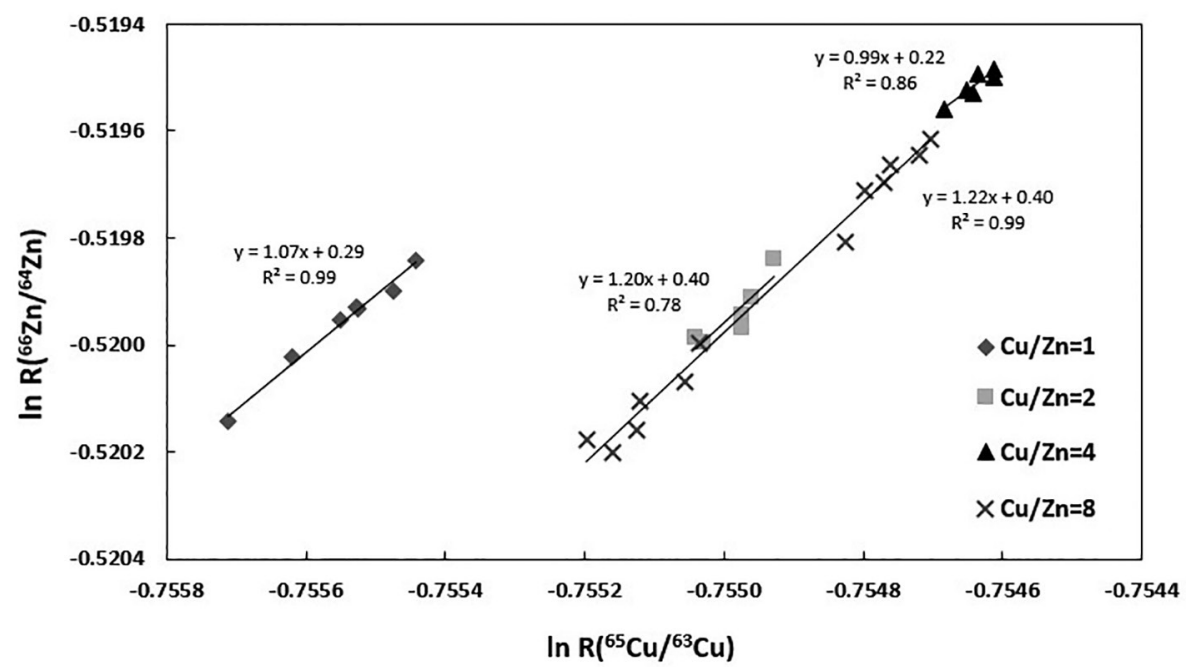

Figure 1. The effect of variable $\mathrm{Cu} / \mathrm{Zn}$ ratios performed on the Neptune USP using the mixed reference isotopic solution (Zn UnB + Cu NIST SRM 976). The $\mathrm{Cu} / \mathrm{Zn}$ ratio of 1 showed the closest slope to the theoretical value (ca. 0.96) and the best coefficient of determination $\left(\mathrm{R}^{2}=0.99\right)$.

reproducibility) is affected by the different $\mathrm{Cu} / \mathrm{Zn}$ ratios and hence the mass bias corrections (Table 5). The best external reproducibility $( \pm 0.02 \%, 2 \sigma, \mathrm{n}=7)$ was obtained using the $\mathrm{Cu} / \mathrm{Zn}$ ratio of 1 and correcting the ratios by external normalization through the exponential law. The $\mathrm{Cu} / \mathrm{Zn}$ ratio of 1 yielded the best correlation and the slope closest to the theoretical value (0.96) indicating that $f(\mathrm{Cu})$ is approximately equal to $f(\mathrm{Zn})$. Therefore, this experiment shows that the higher the coefficient of determination $\left(\mathrm{R}^{2}\right)$ between the natural logarithms of $\mathrm{Cu}$ and $\mathrm{Zn}$, more precise will be the correction by the external normalization. 
Table 5. Accuracy and reproducibility for the isotopic reference solution (Zn UnB + Cu NIST SRM 976) using different methods of mass bias correction and different $\mathrm{Cu} / \mathrm{Zn}$ concentration ratios

\begin{tabular}{lccccc}
\hline $\mathrm{Cu} / \mathrm{Zn}$ concentration ratio & $\delta^{66 / 64} \mathrm{Zn}_{\mathrm{UnB}} \mathrm{SSB}$ average & $2 \sigma$ & $\delta^{66 / 64} \mathrm{Zn}_{\mathrm{UnB}}$ Ext. average & $2 \sigma$ & $\mathrm{n}$ \\
\hline $\mathrm{Cu} / \mathrm{Zn}=1$ & 0.01 & 0.07 & 0.00 & 0.02 & 7 \\
$\mathrm{Cu} / \mathrm{Zn}=2$ & -0.01 & 0.17 & -0.01 & 0.11 & 6 \\
$\mathrm{Cu} / \mathrm{Zn}=4$ & 0.00 & 0.05 & 0.00 & 0.05 & 6 \\
$\mathrm{Cu} / \mathrm{Zn}=8$ & 0.00 & 0.06 & 0.00 & 0.08 & 12 \\
\hline
\end{tabular}

n: number of measurements; SSB: sample standard bracketing; Ext.: external normalization applying the exponential law.

Since instrument mass bias behavior can change day to day, a plot of the measurements of the mixed reference isotopic solution (Zn UnB + Cu NIST SRM 976) analyzed on consecutive days $(\mathrm{n}=121)$ is presented in Figure 2. The results showed that the $\mathrm{Cu} / \mathrm{Zn}$ ratio of 1 maintains the slope of the mass bias line close to 1.0 and a good correlation coefficient on both instruments. Throughout this study, the largest extent of mass bias was observed in the Neptune at UnB (Figure 2).

Summarizing our recent results using different $\mathrm{Cu} / \mathrm{Zn}$ ratios, the use of $\mathrm{Cu}$-doping in the proportion of 1:1 with $\mathrm{Zn}$ (at concentrations of $300 \mu \mathrm{g} \mathrm{L}^{-1}$ ) provided the more constant mass bias and consequently more precise results using the external normalization. Thus, the ratio $\mathrm{Cu} / \mathrm{Zn}$ ratio of 1 was applied to all samples and isotopic reference solution measured in this study.

Assessing spectral and non-spectral interferences effects on $\mathrm{Zn}$ isotopic ratios

The doped isotopic reference solution ( $\mathrm{Zn} \mathrm{UnB} \mathrm{+} \mathrm{Cu} \mathrm{NIST} \mathrm{SRM} \mathrm{976)} \mathrm{with} \mathrm{matrix} \mathrm{elements,} \mathrm{i.e.,}$
$\mathrm{Fe}, \mathrm{Cr}, \mathrm{Al}, \mathrm{Ti}, \mathrm{Mg}$ and $\mathrm{Ca}$, showed a strong effect on the accuracy of the $\delta^{66 / 64} \mathrm{Zn}$ values (Figure 3). Chromium and titanium induced shifts higher than $0.1 \%$ o due to the isobaric oxides and hydroxide ionic species $\left({ }^{48} \mathrm{Ti}^{16} \mathrm{O}\right)^{+},\left({ }^{48} \mathrm{Ti}^{16} \mathrm{OH}\right)^{+}$, $\left({ }^{52} \mathrm{Cr}^{16} \mathrm{O}\right)^{+}$and $\left({ }^{52} \mathrm{Cr}^{16} \mathrm{O}^{1} \mathrm{H}\right)^{+}$, while $\mathrm{Fe}, \mathrm{Al}, \mathrm{Ca}$ and $\mathrm{Mg}$ inducing lower shifts $(<0.1 \%$ o). This pattern was observed in previous studies ${ }^{19,30}$ and suggests that inlet systems and ICPs from different MC-ICP-MS models do not differ with respect to the production of interferences when operating in wet plasma. Mason et al..$^{30}$ found little differences in the formation and/or persistence of matrix related polyatomic species in the VG Axiom or the isoprobe instruments. Our data suggest that the MC-ICP-MS Neptune instrument operated in the wet mode is affected in a similar way to other instruments.

Comparing the isotopic compositions by the different mass bias correction approaches, the external normalization method improved the precision compared to the SSB method. This demonstrates that external normalization is capable of attenuating (but not totally) the matrix effects, reinforcing the importance of chemical separation quality prior the chromatography. As demonstrated by

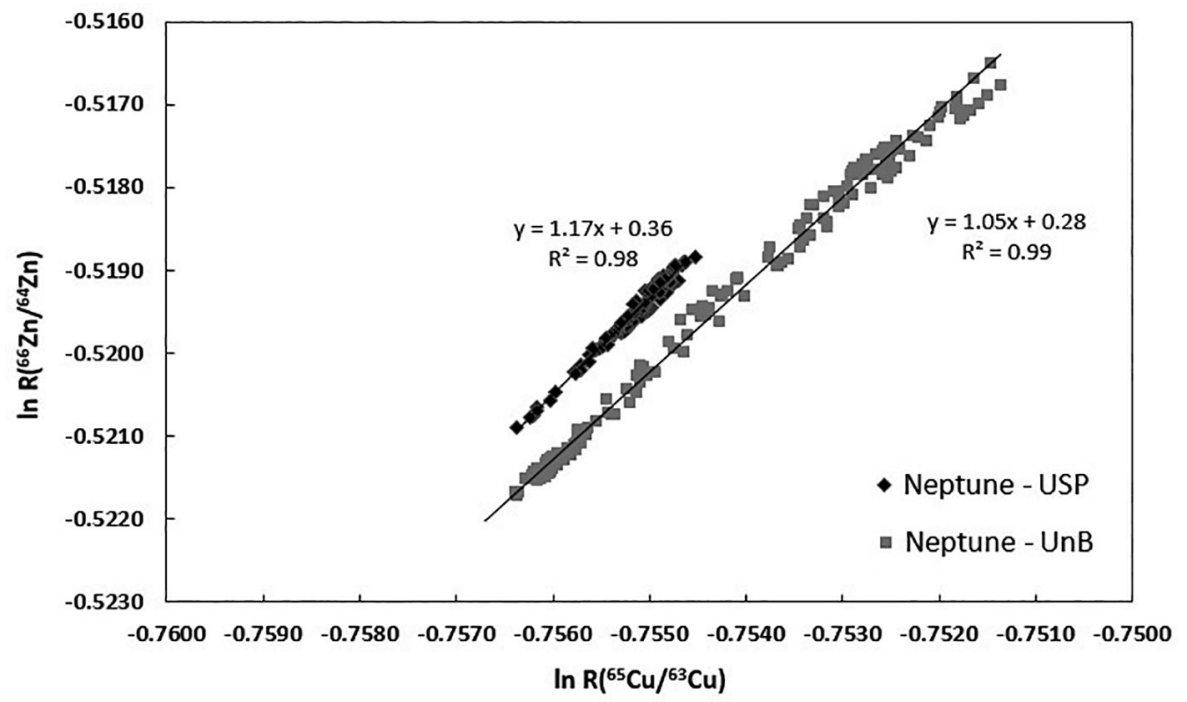

Figure 2. Plot of $\ln \mathrm{R}\left({ }^{66} \mathrm{Zn} /{ }^{64} \mathrm{Zn}\right)$ versus $\ln \mathrm{R}\left({ }^{65} \mathrm{Cu} /{ }^{63} \mathrm{Cu}\right)$ for 121 measurements of the isotopic solution (Zn UnB + Ni NIST 986) over several analytical sessions on consecutive days using the Neptune equipments from USP and UnB universities over a year. The slopes of the mass bias lines obtained in both instruments (1.17 at USP and 1.05 at $\mathrm{UnB}$ ) are close to the theoretical value (ca. 0.96) indicating that $f(\mathrm{Cu})$ is approximately equal to $f(\mathrm{Zn})$. Moreover, both instruments maintained good correlations between the $\mathrm{Cu}$ and $\mathrm{Zn}$ isotopic ratios. In general, the Neptune from UnB showed large mass bias drift over time. 


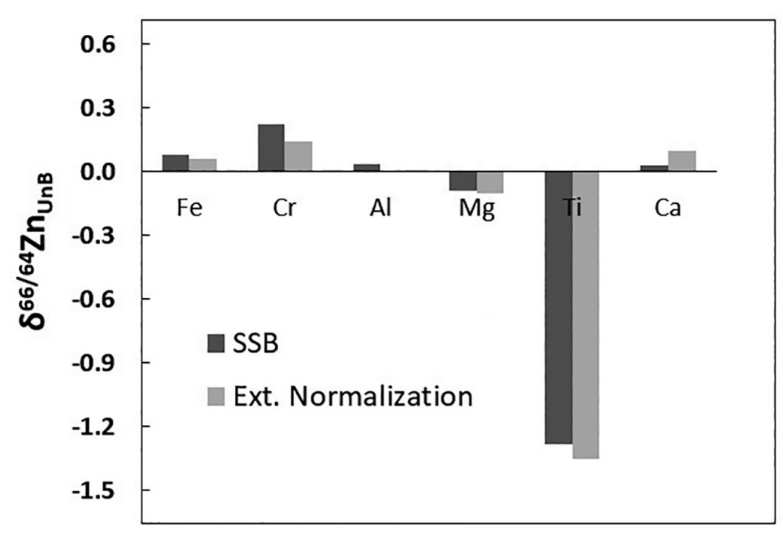

Figure 3. Interference assessed for different elements of the $\mathrm{Zn}$ isotopic compositions. The $\delta$-values of doped mixed reference isotopic solution ( $\mathrm{Zn} \mathrm{UnB} \mathrm{+} \mathrm{Cu} \mathrm{NIST} \mathrm{SRM} \mathrm{976)} \mathrm{were} \mathrm{calculated} \mathrm{against} \mathrm{the} \mathrm{undoped}$ bracketed mixed reference solution using the sample standard bracketing (SSB) and external normalization (Ext.) corrections.

Mason et al. ${ }^{30}$ and Petit et al.,${ }^{19}$ the reductions of oxide and hydroxide ionic species using dry plasma or a second passage through the column are the best alternatives in case of remaining matrix elements on the sample solution. ${ }^{42}$

\section{$\mathrm{Zn}$ isotopic compositions of environmental RMs}

The RM Zn UnB was calibrated against the iCRM Zn IRMM 3702 and the RM Zn JMC 3-0749 during several analytical sessions. The instrumental settings and analytical procedures were the same applied to the samples, using the external normalization for mass bias corrections, $\mathrm{Cu}$-dopant and $\mathrm{Zn}$-analyte matched at concentrations of $300 \mu \mathrm{g} \mathrm{L} \mathrm{L}^{-1}$ and the RM Zn UnB as a bracketed standard. The results are presented in Table 4 and the conversion of the $\delta^{66} \mathrm{Zn}_{\mathrm{UnB}}$ values to $\delta^{6 / / 64} \mathrm{Zn}_{\text {IRMM }}$ and $\delta^{6 / 646} \mathrm{Zn}_{\text {JMC }}$ values is obtained applying the following equations:

$\delta^{66 / 64} \mathrm{Zn}_{\mathrm{UnB}}=\delta^{66 / 64} \mathrm{Zn}_{\mathrm{IRMM}}+0.13 \%$

$\delta^{66 / 64} \mathrm{Zn}_{\mathrm{UnB}}=\delta^{66 / 64} \mathrm{Zn}_{\mathrm{JMC}}-0.14 \%$ \%

The $\delta^{66 / 64} \mathrm{Zn}_{\mathrm{UnB}}$ and $\delta^{66 / 64} \mathrm{Zn}_{\mathrm{JMC}-3-0749 \mathrm{~L}}$ determined for the iCRM Zn IRMM 3702 are presented in Table 4. The $\delta^{66 / 64} \mathrm{Zn}_{\mathrm{JMC}-3-0749 \mathrm{~L}}$ values are shown to enable comparison with the literature since the $\delta^{66 / 64} \mathrm{Zn}_{\mathrm{JMC}}$ continues to be the more widely reported reference standard. Error propagations were used to calculate the error of $\delta^{66 / 64} \mathrm{Zn}_{\mathrm{JMC}}$ values (expressed as $2 \sigma$ ). The corresponding $\delta^{66 / 64} \mathrm{Zn}_{\mathrm{IRMM}}$ values can be obtained using equation 3 .

The external reproducibility $(2 \sigma)$ for replicate measurements ( $\mathrm{n}=2$ to 5 ) of RM with environmental matrices are below $0.1 \%$ (Table 4). For the synthetic RMs Zn UnB and Zn JMC 3-0749, the reproducibilities calculated from 34 measurements in different analytical sessions were 0.08 and $0.06 \%$, respectively.

The RMs BHVO-2 and BCR-2 were used to test critically the analytical accuracy of our analytical procedures as it allows comparison with previously published data (Table 4), while the RMs 2709 San Joaquin soil, 1646a estuarine sediment and 1573a tomato leaves are reported to enable future quality controls of $\mathrm{Zn}$ isotope ratio measurements related to environmental studies. The results of our BHVO-2 and BCR-2 ( $\delta^{66 / 64} \mathrm{ZnJMC}=0.25 \pm 0.09$ and $0.25 \pm 0.10 \%, 2 \sigma$, respectively) are in line with previously published values (Table 4) ranging between 0.2 and $0.3 \%$ o associated to igneous rocks. ${ }^{43}$ The $\delta^{66 / 64} \mathrm{Zn}_{\mathrm{JMC}}$ value for 1646a estuarine sediment $(0.32 \pm 0.07 \%, 2 \sigma, \mathrm{n}=8)$ is close to typical values for igneous rocks, marine sediments and sapropels $(0.23 \pm 0.08 \%$ o, $2 \sigma, \mathrm{n}=20 ; 0.28 \pm 0.02 \%$ o, $2 \sigma$, $\mathrm{n}=3$, respectively). ${ }^{41}$

The $\delta^{6 / 64} \mathrm{Zn}_{\mathrm{JMC}}$ value for the 2709 San Joaquin soil is $0.28 \pm 0.09 \%$ which is close to the $\delta^{66 / 64} \mathrm{Zn}_{\mathrm{JMC}}$ of $0.2 \%$ o suggested for unpolluted soils. ${ }^{44}$ The $\delta^{66 / 64} \mathrm{Zn}_{\text {JMC }}$ values of $0.79 \pm 0.09 \%$ o $(2 \sigma, \mathrm{n}=8)$ for 1573 a tomato are within the large range found in the plant leaves ranging from -0.91 to $0.63 \%$ o for herbaceous species and $0.98 \pm 0.19 \%$ o, $2 \sigma$ for bamboo leaves. ${ }^{7,45}$ The several factors of fractionation such as diffusive processes in cross-cell membrane transport, $\mathrm{Zn}$ bioavailable speciation and rhizosphere reactions ${ }^{46,47}$ probably are associated to this heavy isotopic compositions of 1573a tomato leaves compared with soils and sediments.

\section{Conclusion}

A procedure for determining the $\mathrm{Zn}$ isotopic compositions in environmental samples has been developed through the co-operation between two Brazilian laboratories. The method focused on establishing a simple and fast chromatographic separation of $\mathrm{Zn}$ isotopes from complexes environmental matrices (soils, sediments, rocks and plants), on instrumental controls of mass bias and matrix interferences and on the determinations of $\mathrm{Zn}$ isotopic compositions in reference materials from NIST and USGS.

The chromatographic column calibration experiments showed a fit-for-purpose matrix separation, reproducibility $(<0.01 \%, 5 \leq \mathrm{n} \geq 1,2 \sigma)$ and practically $100 \%$ recovery yields. During analysis sessions, the instruments from both laboratories (ThermoFinnigan Neptune) presented similar mass bias behavior with $f(\mathrm{Zn})$ approximately equal to $f(\mathrm{Cu}$ ). External normalization (Ext.) using $\mathrm{Cu}$ NIST SRM 976 with the dopant/analyte ratio $(\mathrm{Cu} / \mathrm{Zn})$ of 1 produced more precise results than the SSB approach for the mass bias corrections. Investigations on spectral 
and non-spectral interferences in matrix-doped standards identified the formation of $\mathrm{Cr}$ and $\mathrm{Ti}$ oxides and hydroxide ionic species in the plasma as the main interferences on $\mathrm{Zn}$ isotope ratios. Other elements such $\mathrm{Fe}, \mathrm{Ca}, \mathrm{Mg}$ do not produce large interferences, with shifts commonly lower than $0.1 \%$.

Six certified reference materials (USGS and NIST materials) were analyzed: BHVO-2 basalt, BCR-2 basalt, AGV-2 andesite, San Joaquin soil SRM 2709, 1646a estuarine sediment and 1573a tomato leaves. In the case of rock RMs (BHVO-2 basalt, BCR-2 basalt and AGV-2 andesite), the $\delta^{66 / 64} \mathrm{Zn}_{\mathrm{JMC}}$ values were in agreement with values reported in the literature.

This work contributed with a simplified chromatographic protocol for $\mathrm{Zn}$ separation, additional insights about the mass bias processes in the MC-ICP-MS instruments and a new dataset of $\mathrm{Zn}$ isotopic compositions for environmental reference materials in order to fill a gap in the metrological traceability and analytical control of $\mathrm{Zn}$ isotopic data, and stimulate future inter-laboratorial calibrations.

\section{Acknowledgments}

CAPES and CNPq provided scholarships for Daniel Araújo that supported this work. We thank all the laboratory personnel of the Institute of Geosciences at UnB and USP, especially, Erico Zacchi, Myller Tonhá, Fernando Cavalcante and Jeane Chaves for their collaborations in this study. We thank Timothy Mulholland for his substantial support on the English grammar correction. We also thank the two anonymous reviewers for their valuable suggestions and comments.

\section{References}

1. Wiederhold, J.; Environ. Sci. Technol. 2015, 49, 2606.

2. Bullen, T. In Handbook of Environmental Isotope Geochemistry; Baskaran, M., ed.; Springer: Heidelberg, Germany, 2011.

3. Weiss, D.; Rehkdmper, M.; Schoenberg, R.; McLaughlin, M.; Kirby, J.; Campbell, P.; Arnold, T.; Chapman, J.; Peel, K.; Gioia, S.; Environ. Sci. Technol. 2008, 42, 655.

4. Yin, N.; Sivry, Y.; Benedetti, M.; Lens, P.; van Hullebusch, E.; Appl. Geochem. 2016, 64, 128.

5. Sonke, J.; Sivry, Y.; Viers, J.; Freydier, R.; Dejonghe, L.; Andre, L.; Aggarwal, J.; Fontan, F.; Dupre, B.; Chem. Geol. 2008, 252, 145.

6. Peel, K.; Weiss, D.; Siggc, L.; Limnol. Oceanogr. 2009, 54, 1699.

7. Viers, J.; Oliva, P.; Nonell, A.; Gelabert, A.; Sonke, J.; Freydier, R.; Gainville, R.; Dupre, B.; Chem. Geol. 2007, 239, 124.

8. Mulholland, D.; Poitrasson, F.; Boaventura, G.; Allard, T.;
Vieira, L.; Santos, R.; Mancini, L.; Seyler, P.; Geochim. Cosmochim. Acta 2015, 150, 142.

9. Jaouen, K.; Pons, M.; Balter, V.; Earth Planet. Sci. Lett. 2013, 374,164

10. Larner, F.; Woodley, L.; Shousha, S.; Moyes, A.; HumphreysWilliams, E.; Strekopytov, S.; Halliday, A.; Rehkämper, M.; Coombes, R.; Metallomics 2015, 7, 112.

11. Cloquet, C.; Carignan, J.; Lehmann, M.; Vanhaecke, F.; Anal. Bioanal. Chem. 2008, 392, 451.

12. Maréchal, C.; Télouk, P.; Albaréde, F.; Chem. Geol. 1999, 156, 251.

13. Chapman, J.; Mason, T.; Weiss, D.; Coles, B.; Wilkinson, J.; Geostand. Geoanal. Res. 2006, 30, 5.

14. Sossi, P.; Halverson, G.; Nebel, O.; Eggins, S.; Geostand. Geoanal. Res. 2014, 39, 129.

15. Peel, K.; Weiss, D.; Chapman, J.; Arnold, T.; Coles, B.; J. Anal. At. Spectrom. 2008, 23, 103.

16. Irrgeher, J.; Prohaska, T.; Anal. Bioanal. Chem. 2015, 408, 369.

17. Sivry, Y.; Riotte, J.; Sonke, J.; Audry, S.; Schafer, J.; Viers, J.; Blanc, G.; Freydier, R.; Dupre, B.; Chem. Geol. 2008, 255, 295.

18. Thapalia, A.; Borrok, D.; Van Metre, P.; Musgrove, M.; Landa, E.; Environ. Sci. Technol. 2010, 44, 1544.

19. Petit, J.; de Jong, J.; Chou, L.; Mattielli, N.; Geostand. Geoanal. Res. 2008, 32, 149.

20. Weiss, D.; Rausch, N.; Mason, T.; Coles, B.; Wilkinson, J.; Ukonmaanaho, L.; Arnold, T.; Nieminen, T.; Geochim. Cosmochim. Acta 2007, 71, 3498.

21. Conway, T.; Rosenberg, A.; Adkins, J.; John, S.; Anal. Chim. Acta 2013, 793, 44.

22. Chen, J.; Gaillardet, J.; Louvat, P.; Huon, S.; Geochim. Cosmochim. Acta 2009, 73, 4060.

23. Chen, J.; Louvat, P.; Gaillardet, J.; Birck, J.; Chem. Geol. 2009, 259,120

24. Gioia, S.; Weiss, D.; Coles, B.; Arnold, T.; Babinski, M.; Anal. Chem. 2008, 80, 9776.

25. Arnold, T.; Schönbächler, M.; Rehkämper, M.; Dong, S.; Zhao, F.; Kirk, G.; Coles, B.; Weiss, D.; Anal. Bioanal. Chem. 2010, $398,3115$.

26. Costas-Rodríguez, M.; Van Heghe, L.; Vanhaecke, F.; Metallomics 2014, 6, 139.

27. Moeller, K.; Schoenberg, R.; Pedersen, R.; Weiss, D.; Dong, S.; Geostand. Geoanal. Res. 2012, 36, 177.

28. Zhu, Z.; Jiang, S.; Yang, T.; Wei, H.; Int. J. Mass Spectrom. 2015, 393, 34.

29. Albarède, F.; Beard, B. L. In Geochemistry of Non-Traditional Stable Isotopes; Johnson, C. M.; Beard, B. L.; Albarède, F., eds.; Mineralogical Society of America: Washington, USA, 2004, ch. 4.

30. Mason, T.; Weiss, D.; Horstwood, M.; Parrish, R.; Russell, S.; Mullane, E.; Coles, B.; J. Anal. At. Spectrom. 2004, 19, 209. 
31. Mason, T.; Weiss, D.; Horstwood, M.; Parrish, R.; Russell, S.; Mullane, E.; Coles, B.; J. Anal. At. Spectrom. 2004, 19, 218.

32. Archer, C.; Vance, D.; J. Anal. At. Spectrom. 2004, 19, 656.

33. Vogl, J.; Pritzkow, W. In Isotopic Analysis: Fundamentals and Applications Using ICP-MS; Vanhaecke, F.; Degryse, P., eds.; Wiley-VCH Verlag GmbH \& Co. KGaA: Weinheim, Germany, 2012, p. 139.

34. de Laeter, J. R.; Geostand. Geoanal. Res. 2005, 29, 53.

35. Kraus, K.; Moore, G.; J. Am. Chem. Soc. 1953, 75, 1460.

36. Maréchal, C.; Albarède, F.; Geochim. Cosmochim. Acta 2002, 66, 1499.

37. Heumann, G. K.; Gallus, M. S.; Rädlinger, G.; Vogl, J.; J. Anal. At. Spectrom. 1998, 13, 1001.

38. Longerich, H.; Fryer, B.; Strong, D.; Spectrochim. Acta, Part B 1987, 42, 39.

39. Herzog, G.; Moynier, F.; Albarède, F.; Berezhnoy, A.; Geochim. Cosmochim. Acta 2009, 73, 4365.

40. Moynier, F.; Beck, P.; Yin, Q.; Ferroir, T.; Barrat, J.; Paniello, R.; Telouk, P.; Gillet, P.; Chem. Geol. 2010, 276, 374.
41. Maréchal, C.; Nicolas, E.; Douchet, C.; Albarède, F.; Geochem. Geophys. Geosyst. 2000, 1, 1.

42. Dong, S.; Weiss, D.; Strekopytov, S.; Kreissig, K.; Sun, Y.; Baker, A.; Formenti, P.; Talanta 2013, 114, 103.

43. Chen, H.; Savage, P.; Teng, F.; Helz, R.; Moynier, F.; Earth Planet. Sci. Lett. 2013, 369, 34.

44. Fekiacova, Z.; Cornu, S.; Pichat, S.; Sci. Total. Environ. 2015, 517, 96.

45. Moynier, F.; Pichat, S.; Pons, M.; Fike, D.; Balter, V.; Albarède, F.; Chem. Geol. 2009, 267, 125.

46. Jouvin, D.; Weiss, D.; Mason, T.; Bravin, M.; Louvat, P.; Zhao, F.; Ferec, F.; Hinsinger, P.; Benedetti, M.; Environ. Sci. Technol. 2012, 46, 2652.

47. Coutaud, A.; Meheut, M.; Viers, J.; Rols, J.; Pokrovsky, O.; Chem. Geol. 2014, 390, 46.

Submitted: March 3, 2016

Published online: May 31, 2016

FAPESP has sponsored the publication of this article. 